\title{
The Effect of Magnesium Chloride on the Adrenalino-Secretory Action of Potassium Chloride
}

\author{
By
}

\author{
Kazukuni Yamashita, Masaaki Inoue and Hirobumi Akimoto \\ (山下 - 邦) (井上公明) (秋本 博文) \\ From the Department of Physiology, Nagasaki University \\ School of Medicine, Nagasaki; \\ Director: Prof. T. Suzuki
}

(Received for publication, March 17, 1958)

Evidence concerning the antagonistic actions of $\mathrm{K}$ and $\mathrm{Mg}$ ions on the adrenaline secretion of the adrenal was given by Hazard and Wurmser. ${ }^{1)}$ They observed in dogs that the elevation of blood pressure evoked by intravenous injection of $\mathrm{KCl}$ was prevented by $\mathrm{MgCl}_{2}$ and assumed that this was attributable to the antagonistic effect of $\mathrm{MgCl}_{2}$ on the adrenalinosecretory action of $\mathrm{KCl}$.

Their experiment seems to be sufficiently reasonable to know the antagonistic actions of two ions on the cardio-vascular system at least, but we feel there is a need to investigate quantitatively this problem because the blood pressure response is not a specific indicator for the adrenaline secretion of the adrenal.

Thus, the present study was undertaken to elucidate quantitatively whether the accelerated adrenaline secretion causable by $\mathrm{KCl}$ is suppressed by $\mathrm{MgCl}_{2}$.

\section{EXPERIMENTAL \\ Methods}

Dogs, anesthetized by intravenous injection of Evipan-sodium, were used. The operation for collecting the adrenal venous blood was performed through the lumbar route with almost the same technique as that of Satake et al..$^{2}$ The adrenaline content of the blood specimens was determined chemically by the arseno-molybdic acid method of Bloor and Bullen. ${ }^{3)}$ In most experiments the blood pressure was recorded by the mercury manometer connected with the femoral artery.

$\mathrm{KCl}$ in a dose of $30-33 \mathrm{mg}$. per $\mathrm{kg}$. of body weight was injected intravenously in 15 seconds. Twenty to 30 minutes later, a mixture of $\mathrm{KCl}$ in the same amount as before with $\mathrm{MgCl}_{2}$ in an amount of $10 \mathrm{mg}$. per kg. was again injected in- 
travenously in 15 seconds.

Thus, the adrenaline secretion rates after the first and the second injections were estimated and compared with each other. Adrenaline (Merck), dissolved in 1/10 N hydrochloric acid solution, was taken as the reference standard.

\section{Results}

The data obtained from four experiments are epitomized in Table I.

TABLE I

Effect of $\mathrm{MgCl}_{2}$ on the Augmented Adrenaline Secretion Causable by $\mathrm{KCl}$

\begin{tabular}{|c|c|c|c|c|c|c|c|}
\hline \multirow{4}{*}{\multicolumn{2}{|c|}{$\begin{array}{l}\text { No. of exp. } \\
\text { Body weight } \\
\text { and } \\
\text { Sex }\end{array}$}} & \multicolumn{6}{|c|}{ Adrenaline secretion rate ( $\mu \mathrm{g}$. per $\mathrm{kg}$. per minute) } \\
\hline & & \multicolumn{3}{|c|}{ Injection of $\mathrm{KCl}$} & \multicolumn{3}{|c|}{ Injection of $\mathrm{KCl}$ plus $\mathrm{MgCl}_{2}$} \\
\hline & & \multirow{2}{*}{ Before } & \multicolumn{2}{|c|}{ After } & \multirow{2}{*}{ Before } & \multicolumn{2}{|c|}{ After } \\
\hline & & & $0-60^{\prime \prime}$ & $60^{\prime \prime}-120^{\prime \prime}$ & & $0-60^{\prime \prime}$ & $60^{\prime \prime}-120^{\prime \prime}$ \\
\hline 1) & $8.2 \mathrm{~kg}$. & * & 0.09 & 0.02 & 0.005 & 0.01 & 0.006 \\
\hline 2) & $11.1 \mathrm{~kg}$. & * & 0.31 & 0.04 & 0.008 & 0.009 & * \\
\hline 3) & $9.9 \mathrm{~kg}$. & 0.02 & 0.11 & 0.02 & 0.02 & 0.03 & 0.01 \\
\hline 4) & $17.0 \mathrm{~kg}$. & * & 0.38 & 0.06 & 0.02 & 0.10 & * \\
\hline
\end{tabular}

* Immeasurably small

In Exp. 1 the adrenaline content of the blood sample collected before $\mathrm{KCl}$ injection was too small to be quantified. After $\mathrm{KCl}$ a definite increase in the adrenaline secretion rate was found. In the first 60 -second period after the start of injection it was determined as $0.09 \mu \mathrm{g}$. per kg. per minute. With the specimen, which was collected during the second 60 -second period, the rate of secretion was determined as $0.02 \mu \mathrm{g}$.

Thirty minutes later, the rate of secretion was estimated as $0.005 \mu \mathrm{g}$. per kg. per minute. Then the mixture of $\mathrm{KCl}$ with $\mathrm{MgCl}_{2}$ was injected. After injection the rate of secretion did not show any definite alteration.

In Exp. 2, the basal rate of adrenaline secretion at the beginning of experiment was immeasurably small. On receiving $\mathrm{KCl}$ it was increased. With the specimen collected during the first 60 -second period, it was found to be $0.31 \mu \mathrm{g}$. per $\mathrm{kg}$. per minute. In the second 60 -second period it was $0.04 \mu \mathrm{g}$.

Twenty-five minutes later, the rate of secretion was $0.008 \mu \mathrm{g}$. per $\mathrm{kg}$. per minute. The mixture of $\mathrm{KCl}$ with $\mathrm{MgCl}_{2}$ was then injected. After the application the rate of adrenaline secretion was determined as $0.09 \mu \mathrm{g}$. and immeasurably small rate at the first and the second 60 -second period, respectively.

In Exp. 3 the initial adrenaline secretion rate was $0.02 \mu \mathrm{g}$. per $\mathrm{kg}$. per minute. By the administration of $\mathrm{KCl}$, the increase in the adrenaline secretion rate up to $0.11 \mu \mathrm{g}$. was elicited, which was found in the first 60 -second period. In the second 60 -second period the rate of secretion was $0.02 \mu \mathrm{g}$. 
Twenty minutes later, the adrenaline secretion rate of the adrenal was $0.02 \mu$ g. per kg. per minute. Then the injection of $\mathrm{KCl}$ plus $\mathrm{MgCl}_{2}$ was made. By the injection the rate of secretion was not increased definitely.

In Exp. 4, the adrenaline secretion rate after $\mathrm{KCl}$ injection was found to be $0.38 \mu$ g. per kg. per minute in the first 60 -second period against immeasurably small rate before injection. In the next 60 -second period it was $0.06 \mu \mathrm{g}$.

Twenty-two minutes later, the adrenaline secretion rate was $0.02 \mu \mathrm{g}$. per kg. per minute. $\mathrm{By}$ the injection of $\mathrm{KCl}$ plus $\mathrm{MgCl}_{2}$ its value was somewhat increased, $0.10 \mu \mathrm{g}$. being estimated in the first 60 -second period.

From the above results, it was clarified quantitatively that the augmentation of the adrenaline secretion causable by $\mathrm{KCl}$ was suppressed or nullified by $\mathrm{MgCl}_{2}$.

In most cases the blood pressure fell abruptly after $\mathrm{KCl}$ injection and at its lowest level a bradycardia was observed. Then the blood pressure rose again step by step and resumed the initial level. After the injection of the mixture of $\mathrm{KCl}$ with $\mathrm{MgCl}_{2}$, the blood pressure fell in most cases slightly. Soon, it began to rise and reached the pre-injection level.

\section{SUMmary}

Four dogs, anesthetized with Evipan-sodium, were experimented on. The adrenal venous blood specimens were collected through the lumbar route and were analysed for adrenaline by the chemical method of Bloor and Bullen.

While the administration of $\mathrm{KCl}$ in a dose of $30-33 \mathrm{mg}$. per $\mathrm{kg}$. caused a definite increase in the adrenaline secretion, the injection of $\mathrm{KCl}$ in the same dose as before plus $\mathrm{MgCl}_{2}$ in a dose of $10 \mathrm{mg}$. per $\mathrm{kg}$. produced no increase or only a small increase in the adrenaline secretion.

From these experimental results, it is concluded that $\mathrm{MgCl}_{2}$ is capable of antagonizing the accelerating action of $\mathrm{KCl}$ on the adrenaline secretion.

We should like to record our gratitude to Prof. T. Suzuki for suggesting the problem.

\section{References}

1) Hazard, R. \& Wurmser, L., Compt. Rend. Soc. Biol., 1934, 117, 864.

2) Satake, Y., Sugawara, T. \& Watanabe, M., Tohoku J. Exper. Med., 1927, 8, 501.

3) Bloor, W. K. \& Bullen, S. S., J. Biol. Chem., 1941, 138, 727. 